\title{
ПРОБЛЕМЫ ПРАВОВОГО РЕЖИМА ЗЕМЕЛЬ ЛЕЧЕБНО-ОЗДОРОВИТЕЛЬНЫХ МЕСТНОСТЕЙ И КУРОРТОВ
}

Изменения, внесенные в 2013 г. в законодательство, устанавливающее правовой режим особо охраняемых территорий, повлекли за собой исключение из их состава курортов и лечебно-оздоровительные местности. Подверглись корректировки и нормы Земельного кодекса РФ и связанного с ним законодательства, в результате чего возник ряд проблем теоретического и прикладного характера. На сегодняшний день земли курортов отнесены к землям особо охраняемых территорий, но ст. 94 Земельного кодекса РФ, содержащая закрытый перечень земель особо охраняемых территорий, курорты и печебно-оздоровительные местности не упоминает.

Серьезные расхождения обнаруживаются и при сравнительном анализе Земельного кодекса РФ и Ф3 от 13.07.2015 N 218-Ф3 (ред. от 25.12.2018) «О государственной регистрации недвижимости», а также Градостроительным кодексом в части установления границ зон округа санитарной (горно-санитарной) охраны.

Базовым источником правового регулирования режима лечебно-оздоровительных местностей и курортов является Ф3 от 23.02.1995 г. №26-Ф3 (ред. от 28.12.2013) «О природных лечебных ресурсах, лечебно-оздоровительных местностях и курортах», однако и он не в полной мере отвечает реальным потребно- стям в регулировании отношений санаторно-курортного комплекса из-за своей фрагментарности и неполноты. Требуется существенная корректировка курортного законодательства, что придает теме проведенного исследования актуальность.

В статье проводится детальный анализ элементов правового режима земель курортов, включая анализ правового режима зон округов санитарной (горно-санитарной) охраны курортов.

Наряду с исследованием действующего законодательства в статье приводится характеристика изменений, которые планируется внести в нормативные правовые акты, регулирующие земельно-правовую сферу курортных отношений и делается вывод о том, что новеллы в случае их принятия приведут к необоснованной либерализации существующего правового режима земель зон округа санитарной (горно-санитарной) охраны курортов.

По итогам проведенного исследования формулируются выводы, обладающие новизной, касающиеся совершенствования правового режима земель курортов.

Ключевые слова: курорты, лечебно-оздоровительные местности, земли, округ санитарной (горно-санитарной) охраны.

\section{E. Navasardova, G. Chechel, R. Nutrikhin}

\section{THE PROBLEMS OF THE LEGAL REGIME OF LANDS} OF HEALTH-IMPROVING AREAS AND RESORTS

Changes made to the legislation establishing the legal regime of specially protected areas in 2013resulted in the exclusion of resorts and health-improving areas from their content. The norms of the Land code of the Russian Federation and related legislation were also amended, resulting in a number of theoretical and applied problems. To date, the land of the resorts referred to the lands of specially protected areas on Art. 94 of the Land code of the Russian Federation, containing the closed list of lands of especially protected territories, resorts and health-improving areas are not mentioned.

Serious discrepancies are found both at the comparative analysis of the Land code of the Russian Federation and FL of 13.07.2015 N 218-FL (edition of 25.12.2018) "On state registration of real estate", and also the town-planning code regarding establishment of borders of zones of the district of sanitary (mounting and sanitary) protection.

The basic source of legal regulation of the regime of health-improving areas and resorts is the Federal law of 23.02.1995 №26-FL (ed. of 28.12.2013) "On natural healing resources, health-improving areas and resorts", howev- er, it does not fully meet the real needs in the regulation of relations of the health-resort complex because of its fragmentation and incompleteness. A significant adjustment of the resort legislation is required, which makes the topic of the study relevant.

The article provides a detailed analysis of the elements of the legal regime of resort lands, including the analysis of the legal regime of the district of sanitary (mounting and sanitary) protection of resorts.

Along with the study of the current legislation, the article describes the changes that are planned to be made to the normative legal acts regulating the land and legal sphere of resort relations and concludes that the novelties, if adopted, will lead to unjustified liberalization of the existing legal regime of land areas of the district of sanitary (mounting and sanitary) protection of resorts.

According to the results of the study, the conclusions with novelty concerning the improvement of the legal regime of land resorts are formulated.

Key words: resorts, health-improving areas, lands, the district of sanitary (mounting and sanitary) protection. 
На сегодняшний день в России создана обширная законодательная база в санаторно-курортной copepe, а в последние годы ведется еще и большая законопроектная работа, направленная на совершенствование правового режима лечебно-оздоровительных местностей (далее - ЛОМ) и курортов [1, с. 119], а также соответствующих земель, являющихся пространственно-территориальным базисом для размещения курортной инфраструктуры. Идет напряженный поиск оптимальных юридических средств и нормативных алгоритмов, могущих способствовать сохранению природоресурсного потенциала отечественных курортов, способных помочь преодолеть их начавшуюся стагнацию и задать вектор их дальнейшего развития.

Наряду с неизбежными трудностями теоретико-правового и юридико-технического характера совершенствование законодательства в данной сорере наталкивается на серьезные лоббистские преграды. Вопрос о правовом режиме курортов и соответствующих земель оказывается в фокусе самых разных, прежде всего, экономических интересов. Поскольку лейтмотивом правовых норм, направленных на охрану лечебно-оздоровительных местностей и курортов, на рациональное использование их земельных и иных природных ресурсов, являются всевозможные запреть и ограничения, то на содержание данных норм пытаются влиять представители строительного и иного бизнеса, муниципальные власти и другие субъекты, заинтересованные в беспрепятственном осуществлении хозяйственной деятельности на этих особо охраняемых территориях, в предоставлении там земель и прочих очевидных выгодах, которые соответствующее законодательство как раз и призвано ограничить с целью сохранения лечебно-оздоровительных местностей и курортов для настоящего и будущих поколений.

Неприкосновенность, с одной стороны, приоритета санаторно-курортного назначения рассматриваемых земель перед иными видами их хозяйственного использования, а также приверженность законодателя природоохранному характеру соответствующих правовых норм, а, с другой снятие излишних законодательных барьеров, которые могут мешать развитию данных территорий, должно способствовать более эффективному совершенствованию курортного законодательства на современном этапе [5, с. 168]

Отражение правовых реалий курортной сферы в нормах Земельного кодекса РФ сопряжено с большим количеством проблем теоретического и прикладного характера. Правовой режим земель ЛОМ и курортов (ст. 96) определен в главе XVII «Земли особо охраняемых территорий и объектов», однако в ч. 2 ст. 94 ЗК РФ, где содержится закрытый перечень видов земель этой категории, земли ЛОМ и курортов даже не упомянуты. Там упоминаются земли особо охраняемых природных территорий, однако ЛОМ и курорты к ООПТ давно не относятся. Так что неясно, в какой категории земель должны быть отнесены сегодня земли ЛОМ и курортов. По расположению статьи о них в главе XVII напрашивается вывод, что к землям особо охраняемых территорий и объектов. Однако для этого указание на земли ЛОМ и курортов необходимо ввести в ч. 2 ст. 94 ЗК РФ.

В настоящее время основным источником правового регулирования режима лечебно-оздоровительных местностей и курортов является Федеральный закон от 23.02.1995 г. №26-Ф3 «О природных лечебных ресурсах, лечебно-оздоровительных местностях и курортах) (далее Закон №26-Ф3), который закрепил основные нормативные положения о ЛОМ и курортах, а также правовые принципы их защиты как особо охраняемых объектов и территорий, являющихся национальным достоянием народов Российской Федерации. Вместе с тем, данный закон не в полной мере отвечает реальным потребностям в регулировании отношений санаторно-курортного комплекса из-за своей фрагментарности и очевидной неполноты. Примером этого может служить определяемый законом режим санитарной (горно-санитарной) охраны природных лечебных ресурсов. С этой целью на территории ЛОМ и курортов устанавливается округ санитарной (горно-санитарной) охраны, внутри которого выделяется до трех зон, для каждой из которых предусмотрены определенные ограничения хозяйственной деятельности. Каждая из этих зон должна иметь строго определенные, засиксированные границы. Однако Закон №26-Ф3 ничего не говорит о границах $30 н$, а только о границах округа санитарной (горно-санитарной) охраны ЛОМ и курортов (абз. 3 ст. 4, ч. 2 ст. 16 и др.). Это создает нежелательную терминологическую неопределенность. Возможно, что, говоря о границах округа санитарной (горно-санитарной) охраны ЛОМ и курортов законодатель подразумевал и границы трех зон внутри этого округа, но из текста закона это не вполне очевидно. Для полной ясности в Законе №26-Ф3 должна идти речь как о границе округа санитарной (горно-санитарной) охраны (она же граница территории ЛОМ или курорта), так и о границах зон внутри такого округа (внешний контур последней зоны совпадает с границей территории ЛОМ или курорта). Причем все виды этих границ должны устанавливаться и при необходимости изменяться одним и тем же органом исполнительной власти (для курортов федерального значения - Правительством РФ)

Наличие указанной терминологической неопределенности привело к тому, что в ряде существующих законопроектных инициатив их разработчики предлагают уже, чтобы границы округа санитарной (горно-санитарной) охраны курортов федерального значения устанавливались Правительством РФ, а границы зон внутри такого округа - уполномоченным Правительством федеральным органом исполнительной власти, что на наш взгляд, совершенно недопустимо. Границы этих зон определяют конкретику территориального ограничения отдельных видов хозяйственной деятельности на курортах, что, по факту, 
оказывается более важным для их охраны, чем просто определение внешней границы территории курорта. Решение столь значимого вопроса на более низком уровне может привести к злоупотреблениям и стать явным коррупциогенным фактором. Во избежание этого необходимо четко прописать в Законе №26-Ф3, что Правительство РФ устанавливает как границы округа санитарной (горно-санитарной) охраны ЛОМ и курортов, так и границы зон внутри такого округа. Изменение этого порядка может привести к произвольной трансформации границ указанных зон, что повлечет за собой деградацию природоресурсного потенциала курортов федерального значения [9, с.99].

Сам правовой режим трех зон округа санитарной (горно-санитарной) охраны ЛОМ или курорта прописан в законе весьма поверхностно (ч. 3 ст. 16). Куда более детально он урегулирован п.п. 12-14 Постановления Правительства РФ от 07.12.1996 г. №1425 «Об утверждении Положения об округах санитарной и горно-санитарной охраны лечебно-оздоровительных местностей и курортов федерального значения». Думается, что ограничение хозяйственной деятельности в зонах округа санитарной (горно-санитарной) охраны ЛОМ или курорта является принципиально важным вопросом для этой ссреры отношений, в виду чего его регулирование нормами подзаконного акта не вполне уместно. Указанные нормы Постановления Правительства РФ от 07.12.1996 г №1425, детально конкретизирующие правовой режим трех зон, необходимо перенести в Закон №26-Ф3. В данном подзаконном акте должны остаться только те нормы, которые регулируют особенности установления таких зон.

Помимо природных лечебных ресурсов ЛОМ и курорты обладают иными природными ресурсами - в частности, землями, лесами и другими зелеными насаждениями, водными объектами, животным миром и др., - которые не только представляют собой значительную эстетическую ценность, но и образуют экосистемы ЛОМ и курортов. Сегодня ч. 3 ст. 2 Федерального закона от 23.02.1995 г. №26-Ф3 «О природных лечебных ресурсах, лечебно-оздоровительных местностях и курортах» определяет, что отношения, связанные с использованием и охраной природных ресурсов, не отнесенных к лечебным, регулируются земельным, водным, лесным и иным законодательством о природных ресурсах.

Вместе с тем, на наш взгляд, природоресурсным законодательством правовой режим перечисленных природных ресурсов на курортах урегулирован не в достаточной степени. Например, пп. «д» п. 3 ч. 2 ст. 102 Лесного кодекса РФ все леса, расположенные в первой, второй и третьей зонах округов санитарной (горно-санитарной) охраны ЛОМ и курортов относит к категории защитных. Вместе с тем, Лесной кодекс недостаточно полно и эфффективно определяет порядок охраны защитных лесов в России, и их режим требует очевидного усиления. В федеральном законодательстве необходима норма, запрещающая перевод земель лесного фонда на терри- тории ЛОМ и курортов в земли иных категорий кроме как в земли особо охраняемых территорий и объектов. Необходимы нормы, защищающие и городские леса на курортах от сокращения их площади и их застройки. Следует предусмотреть и нормы о том, что все леса, парки, скверы и зеленые массивы на территории курортов должны в обязательном порядке включаться в зеленый лесопарковый пояс соответствующих населенных пунктов, согласно ст. 62.1-62.5 Федерального закона от 10.01.2002 г. №7-Ф3 «Об охране окружающей среды». Это обосновывается огромной средо- и климатообразующей ролью лесов на бальнеологических курортах, их значением для поддержания влажности почв и гидрологического баланса, от чего напрямую зависит экологическое благополучие курортных территорий

Говоря о недостатках Закона №26-Ф3, нельзя не отметить, что в последнее время ведется активная законотворческая работа, нацеленная на изменение данного закона, а также иного федерального законодательства о курортах [4, c. 162]. Обратим внимание на проект №555658-6 Федерального закона «О внесении изменений в Земельный кодекс Российской Федерации, Градостроительный кодекс Российской Федерации и отдельные законодательные акты Российской Федерации” (далее - законопроект). Важность данного проекта очевидна, поскольку в нем предпринята попытка восполнить пробелы и разрешить противоречия, возникшие за последние годы в законодательстве о лечебно-оздоровительных местностях и курортах. Однако актуальная на сегодняшний день редакция документа содержит ряд положений, которые могут привести не к улучшению, а к ухудшению ситуации в этой области отношений.

Среди прочих, весьма многочисленных недостатков данного законопроекта в нем наблюдается тенденция к изменению существующего порядка управления курортами в сторону передачи некоторых важных полномочий на более низкий уровень. В частности, установление и изменение границ округа горно-санитарной охраны курортов фредерального значения в настоящее время осуществляется Правительством РФ (Ч. 2 ст. 16 Закона №26-Ф3). Разработчики законопроекта предлагают наделить полномочиями по принятию соответствующих решений федеральный орган исполнительной власти, уполномоченный на это Правительством. Из ст. 96 Земельного кодекса РФ законопроектом изымается положение о том, что границы и режим округов санитарной (горно-санитарной) охраны курортов, имеющих федеральное значение, устанавливаются Правительством РФ. В этом усматривается стремление упростить существующий порядок установления и изменения указанных границ в интересах хозяйствующих субъектов и застройщиков, но никак не в целях охраны природно-лечебных ресурсов, на страже которых должно стоять государство в лице своего высшего органа исполнительной власти - Правительства РФ [3, с. 103]. По нашему мнению, в федеральном законодательстве 
должны быть сохранены нормы о том, что границы округов санитарной (горно-санитарной) охраны для лечебно-оздоровительных местностей и курортов федерального значения утверждаются Правительством. Только так может быть обеспечено принятие соответствующих решений на достаточно высоком государственном уровне С этой точки зрения передача указанных полномочий от Правительства РФ одному из фредеральных министерств представляется крайне нежелательной.

Имеется немало вопросов к прописанному в законопроекте новому правовому режиму трех зон округа санитарной (горно-санитарной) охраны на курортах. В настоящее время осуществление хозяйственной деятельности в данных зонах регламентируется Законом №26-Ф3 и принятым в соответствии с ним «Положением об округах санитарной и горно-санитарной охраны лечебно-оздоровительных местностей и курортов федерального значения», которое было утверждено Постановлением ПравительстваРФот07.12.1996г №1425

Думается, что в процессе совершенствования данного правового института определяемый им режим хозяйственной деятельности в трех зонах округа санитарной (горно-санитарной) охраны должен быть по своим стандартам не ниже существующего. Точечное или повсеместное смягчение этого режима может привести к самым нежелательным последствиям, однако именно это и предлагается рассматриваемым законопроектом.

Сегодня в первой зоне на курортах федерального значения запрещается: проживание и все виды хозяйственной деятельности, за исключением работ, связанных с исследованиями и использованием природных лечебных ресурсов в лечебных и оздоровительных целях при условии применения экологически чистых и рациональных технологий. Однако законопроект допускает например, размещение в первой зоне средств связи. Понятно, что такая деятельность не имеет никакого отношения к исключительно лечебно-оздоровительным целям создания этой зоны. Предлагаемая норма выглядит как средство устранения «экологических барьеров» на пути реализации интересов мобильных операторов и иных субъектов сфреры услуг связи - явно не в целях сохранения курортов.

Таким образом, предлагаемое законопроектом изменение режима хозяйствования в зонах округа санитарной (горно-санитарной) охраны таят в себе серьезную опасность. В случае принятия законопроекта №555658-6 будет снят существующий на протяжении нескольких десятилетий запрет на строительства в первой зоне. При этом возведение объектов недвижимости станет возможным не только для лечебных и оздоровительных, но и для туристско-рекреационных, физкультурно-оздоровительных и спортивных целей. По факту же, строительство, например, спортивного стадиона или торгового оздоровительно-развлекательного центра в непосредственной близости от оголовка скважины или контура очага разгруз- ки минеральных вод, либо от нулевых границ залежи лечебных грязей (все это первая зона) неизбежно приведет к бактериальному и химическому загрязнению, а следом и к неизбежной деградации природных лечебных ресурсов российских курортов.

На территории второй зоны округа санитарной (горно-санитарной) охраны курортов федерального значения в настоящий момент запрещается: размещение объектов и сооружений, не связанных непосредственно с созданием и развитием сферы курортного лечения и отдыха, а также проведение работ, загрязняющих окружающую среду, природные лечебные ресурсы и приводящих к их истощению. В рассматриваемом законопроекте столь категоричный запрет отсутствует. Там не допускается лишь строительство и размещение объектов, оказывающих особо негативное воздействие на окружающую среду. Такое смягчение режима второй зоны также представляется недопустимым. Законопроект не исключает строительства во второй зоне многоэтажных жилых домов, торговых центров и других зданий, не имеющих никакого отношения к санаторно-курортному лечению и рекреации, тогда как их возведение во второй зоне должно быть в обязательном порядке ограничено по вполне понятным причинам как это и определено в действующем законодательстве. Если мы хотим сохранить курорты, то смягчать эту норму тоже нельзя.

Сейчас для третьей зоны на всех курортах федерального значения законодательством установлены ограничения на размещение промышленных и сельскохозяйственных организаций и сооружений, действует запрет на осуществление хозяйственной деятельности, сопровождающейся загрязнением окружающей среды, природных лечебных ресурсов и их истощением. Рассматриваемый законопроект никаких конкретных ограничений такого рода не предусматривает. В границах третьей зоны округа санитарной (горно-санитарной) охраны он допускает осуществление любой деятельности при соблюдении общих нормативов охраны окружающей среды. То есть никаких специальных запретов для третьей зоны в законопроекте нет. И совершенно уже неясно, в чем состоит особый режим этой зоны? Для чего она вообще создается? К чему сводится смысл ее существования? Не вызывает сомнений, что размещение, к примеру, мест для долговременного захоронения павших от инфекционных болезней сельскохозяйственных животных (данная деятельность не противоречит общим нормативам охраны окружающей среды) в третьей зоне округа санитарной (горно-санитарной) охраны бальнеологических курортов губительно скажется на качестве минеральных вод, поскольку именно здесь происходит водосбор при формировании их источников.

Можно сделать вывод, что законопроект допускает необоснованную либерализацию существующего правового режима трех зон округа санитарной (горно-санитарной) охраны курортов. 
Это может быть выгодно, прежде всего, застройщикам, но никак не отвечает интересам общества по сохранению природных лечебных ресурсов и охране окружающей среды на курортах. Понятно, что при существующем порядке возникает немало проблем, связанных с дисбалансом довольно строго режима трех зон и необходимостью развития урбанистской инфраструктуры. Однако решать эти проблемы нужно не всеохватным ослаблением действующих запретов, введенных с благой целью сохранения природоресурсного курортного потенциала, а путем разработки более сложных инструментов дифференцированного правового регулирования.

Выявленные проблемы позволяют говорить об обозначившейся тенденции к «деэкологизации» курортного законодательства. Существующие в нем ограничения и запреты, очевидно, рассматриваются некоторыми лоббистами как нежелательные «преграды» и «препоны» на пути осуществления хозяйственной деятельности и реализации всевозможных бизнес-интересов. При этом как-то забывается о том, что упраздняемые запреты и ограничения устанавливались вовсе не против бизнеса как такового, а в целях сохранения курортов как бесценного природоресурсного достояния, как неотьемлемого компонента национальной системы здравоохранения. Ведь даже при самом прагматичном подходе к регулированию данных отношений все же следует признать, что без сбережения здоровья всякий рост благосостояния общества лишается какого-либо рационального смысла

Мы уже неоднократно отмечали, что в качестве важнейшего инструмента правовой охраны ЛОМ и курортов должно рассматриваться установление на их территории округа санитарной (горно-санитарной) охраны и выделение внутри него до трех зон. При этом на курортах федерального значения в целях их эффективной охраны органы власти настаивают на необходимости оформления земельных участков, расположенных в первой зоне округа санитарной (горно-санитарной) охраны, в государственную федеральную собственность с установлением запрета на их предоставление, а также на четком закреплении закрытого перечня видов деятельности во второй и третьей зонах. Это вполне логичное и обоснованное предложение, которое в отдельных субъектах Федерации уже начало реализовываться на практике, следовало бы закрепить в федеральном законодательстве.

Не нуждается в лишних пояснениях тезис о том, что выделения трех зон округа санитарной (горно-санитарной) охраны еще слишком мало для того, чтобы эффективно обеспечить для каждого из них режим ограничения хозяйственной деятельности. Границы каждой из этих зон должны быть четко определены и засиксированы путем кадастрирования. И тут тоже возникает немало проблем, в том числе и законодательного характера

Сегодня даже на курортах федерального значения сведения далеко не обо всех границах зон округа санитарной (горно-санитарной) охраны зафиксированы в кадастре недвижимости. Без этого подчас невозможно определить, что конкретный земельный участок относится к той или иной зоне, а, следовательно, и определенные виды деятельности на нем запрещены.

Существующую систему учета земельных ресурсов призвана усовершенствовать идущая сейчас в стране кадастровая реформа, наиболее значительным шагом которой стало принятие Федерального закона от 13.07.2015 г. №218-Ф3 "О государственной регистрации недвижимости» (далее - Закон №218-ФЗ). В соответствии с новым законом то, что раньше было «Государственным кадастром недвижимости», отныне именуется «Реестром объектов недвижимости (кадастром недвижимости)», который наряду с Реестром прав на недвижимость и Реестром границ входит теперь в Единый государственный реестр недвижимости (ЕГРН). Понятно, что система новая, и ее конкретное содержательное наполнение, равно как и особенности порядка дальнейшего ведения еще не до конца ясны. В частности, по новому закону вовсе не очевидно, что сведения о границах округа санитарной (горно-санитарной) охраны курорта и зон внутри него должны вноситься именно в кадастр недвижимости. Там, конечно, предусмотрены раздель об ограничениях и обременениях прав на землю, к чему можно подвести и режим округа санитарной (горно-санитарной) охраны, однако вовсе не факт, что такие сведения будут заноситься работниками Росреестра именно туда. Ведь наряду с кадастром недвижимости у нас появился еще и Реестр границ, где, в частности, будут содержаться сведения о границах зон с особыми условиями использования.

Казалось бы, это нововведение должно упростить фиксацию границ округа санитарной (горно-санитарной) охраны, а также зон внутри него. Однако ни ст. 7, ни ст. 10 Закона №218-Ф3, детально регулирующая содержание Реестра границ, не упоминает ни о границах округа санитарной (горно-санитарной) охраны ЛОМ и курортов, ни о границы зон внутри него. О границах таких «территорий с особыми условиями использования» законодатель, по-видимому, просто забыл, оставив этот вопрос без должного регулирования.

Для обеспечения надежной фиксации названных границ необходимо внести изменения в ст. 7 , 10 и другие нормы Закона №218-Ф3, предусмотрев обязательную регистрацию границ ЛОМ и курортов, а также границ зон округов их санитарной (горно-санитарной) охраны в реестре границ $\mathrm{E} \mathrm{PPH}$.

Не лучше обстоит дело с этими зонами и в градостроительном законодательстве. Так, ч. 4 ст. 1 Градостроительного кодекса РФ при определении «зон с особыми условиями использования территорий» также не упоминает округа санитарной (горно-санитарной) охраны ЛОМ и курортов.

Недавно Федеральным законом от 03.08.2018г №342-Ф3 в Земельный кодекс РФ была введена новая XIX глава о зонах с особыми условиями ис- 
пользования территорий. Часть 15 ст. 105, в отличие от норм Градостроительного кодекса и Закона №218-Ф3, в числе таких зон все же называет «округ санитарной (горно-санитарной) охраны лечебно-оздоровительных местностей, курортов и природных лечебных ресурсов», однако опять же не дает конкретизированного указания на три зоны внутри данного округа. Смущает и диспозитивная формулировка новой ст. 105 ЗК РФ («могут быть установлены следующие виды зон...») что в совокупности опять же не дает гарантий фиксации таких зон в актах градостроительного планирования и в градостроительных регламентах. Думается, что фформулировка данной статьи должна быть более определенной.

Градостроительный кодекс РФ вообще крайне неудовлетворительно отражает правовые реалии курортной сферы. Так, в ч. 6 ст. 36 и п. 6 ч. 5 ст. 51 ГрадК РФ говорится соответственно о землях и границах «особо охраняемых природных территорий (за исключением земель лечебно-оздоровительных местностей и курортов)», тогда как предусматривать здесь ЛОМ и курорты в качестве исключений уже не корректно, поскольку они с 2013 года больше не относятся к ООПТ.

Остановимся подробнее на том, как эта проблема вообще возникла и какие имела последствия для российского курортного законодательства. До принятия Федерального закона от 28.12.2013 г. №406-Ф3 «О внесении изменений в Федеральный закон "Об особо охраняемых природных территориях" и отдельные законодательные акты Российской Федерации» ЛОМ и курорты относились к особо охраняемым природным территориям (далее - ООПТ). Указанным законом ЛОМ и курорты из перечня ООПТ были исключены, и сегодня они определяются в Законе №26Ф3 просто как некие «особо охраняемые объекты и территории» (см. преамбулу). Столь серьезное реформирование правового статуса ЛОМ и курортов в России потребовало внесения соответствующих изменений в целый ряд норм федеральных и региональных законов и подзаконным актов для того, чтобы привести правовое регулирование их режима в строгое соответствие с новым статусом ЛОМ и курортов. Однако эта кропотливая работа по реформированию законодательства о курортах была проведена не в полной мере.

Проблема изменения правового статуса российских ЛОМ и курортов в 2013 г. вообще крайне негативно отразилась на институте юридической ответственности за нарушение их режима. Ст. 20 Закона №26-Ф3, посвященная ответственности за нарушение правового режима ЛОМ и курортов, просто отсылает к уголовному, административному и иному законодательству. Однако в соответствующих федеральных законах данной ответственности попросту не установлено. Ранее, когда ЛОМ и курорты еще относились к ООПТ, уголовная ответственность за нарушение их правового режима наступала по ст. 262 УК РФ «Нарушение режима особо охраняемых природных территорий и природных объектов», а административная ответственность - по ст. 8.39 КоАП
РФ «Нарушение правил охраны и использования природных ресурсов на особо охраняемых природных территориях». Однако, так как деятельность этих норм распространяется только на ООПТ, а ЛОМ и курорты ими больше не являются, то последние, как следствие, фактически остались без надлежащей уголовно-правовой и административной защиты. Необходимо дополнить ст. 262 Уголовного кодекса РФ и ст. 8.39 Кодекса Российской Федерации об административных правонарушениях нормами об уголовной и административной ответственности соответственно за нарушение правового режима ЛОМ и курортов наряду и по аналогии с юридической охраной ООПТ, коль скоро ЛОМ и курорты к ним больше не относятся. Отсутствие упоминания о них в ст. 262 УК РФ и ст. 8.39 КоАП РФ стало серьезным упущением при реформировании правового статуса ЛОМ и курортов в 2013 году, из чего можно заключить, что федеральное законодательство до сих пор не в полной мере приведено в соответствие с их ресрормированным статусом

Практические проблемы реализации правового режима земель ЛОМ и курортов можно проиллюстрировать на примере ситуации, сложившейся в эколого-курортном регионе федерального значения Кавказские Минеральные Воды. Говоря - правовом режиме земель, мы имеем в виду особенности правового регулирования имущественных прав, публичного управления, прав и обязанностей правообладателей и должностных лиц, ответственных за состояние земель и природных лечебных ресурсов, правовые меры охраны и ответственность за нарушение правового режима использования и охраны земель и иных природных ресурсов курортов

Земли курортов, во-первых, не являются самостоятельной категорией, а входят в состав земель особо охраняемых территорий и объектов

Во-вторых, что бы ни говорили о порочности идеи двойного режима земель, считая единственно верной позицию, «полностью опровергающую высказывания о возможности “совмещения правовых режимов земель» [2, с. 31], проблема существует и ее, на наш взгляд, следует обсуждать.

Как известно, ЗК РФ признает землями лечебно-оздоровительных местностей и курортов те земли, которые предназначены для лечения и отдыха граждан. Как следует далее из нормы ст. 96 ЗК РФ, в состав этих земель включаются земли, обладающие природными лечебными ресурсами, которые используются или могут использоваться для профилактики и лечения заболеваний человека. Логика в такой компоновке предложений отсутствует: сначала обозначили следствие предназначенные для лечения, а потом назвали причину - наличие природных лечебных ресурсов. Ведь лечиться можно и в поликлинике, а отдыхать на даче. Видимо поэтому в проекте $Ф 3$ № 555658-6 «О внесении изменений в Земельный кодекс РФ, Градостроительный кодекс РФ и отдельные законодательные акты РФ», прошедшем первое чтение в сентябре 2014 г, фрормулировку привели в соответствие со здравым 
смыслом. Если закон будет принят, то звучать она будет так: «Земли, обладающие природными лечебными ресурсами, предназначены для организации профилактики и лечения заболеваний и отдыха населения".

Границы территории (надо полагать и земель) курортов федерального значения определяются согласно постановлению Правительства РФ от 07.12.1996 г. №1425 «Об утверждении Положения об округах санитарной и горно-санитарной охраны лечебно-оздоровительных местностей и курортов федерального значения", а в отношении курортов КМВ также соответствующими постановлениями Совета Министров РСФСР [8] и Правительства РФ [7], утвердивших положения о курортах КМВ, и проходят по внешнему контуру округа санитарной (горно-санитарной) охраны.

В нашем случае границы курортов КМВ проходят по территории Ставропольского края, Кабардино-Балкарии и Карачаево-Черкессии, занимая площадь 5,8 тыс. кв. км. Но вот парадокс: земель курортов мы там не найдем. В Ставропольском крае не зарегистрировано ни одного участка в качестве земель курортов. Таким образом, земли курортов, если законодатель признает наличие таких земель, не имеют самостоятельного значения.

Единственная информация, поступающая в территориальные органы Росреестра по Ставропольскому краю при регистрации прав на недвижимое имущество, это информация о том, что земельный участок расположен в пределах курорта - требования к режиму зон горно-санитарной охраны, которые, согласно ст. 56 ЗК РФ, регистрируются в качестве ограничений пользования земельными участками. Причем сведения поступают только в отношении первой и второй зон. Третья зона, по существу, выпадает из ограничений, предусмотренных постановлением Правительства РФ от 07.12.1996 г. №1425 «Об утверждении Положения об округах санитарной и горно-санитарной охраны лечебно-оздоровительных местностей и курортов федерального значения». Ограничения пользования земельными участками по этой зоне даже не регистрируются.

Так можно ли говорить о двойном режиме земель применительно к землям курортов КМВ?

На территории курортов Кавказских Минеральных вод располагаются земли и земельные участки, принадлежащие, скажем, большинству известных земельному законодательству категорий и подкатегорий земель. Выходы используемых минеральных вод на поверхность, что происходит в ряде случаев, расположены на землях населенных пунктов. Как известно, в границах населенных пунктов существуют земли только данной категории. На этих землях действуют режимы первой и, как правило, второй зон горно-санитарной охраны, известны случаи наличия на этих землях и третьей охранной зоны

За границей земель населенных пунктов, где также имеют место выходы минеральных вод на поверхность, зоны охраны в большинстве случаев просто не устанавливаются. Однако здесь имеют место все возможные категории (за исклю- чением земель курортов), включая земли особо охраняемых природных территорий, в частности, земли государственных природных заказников. Большинство земель за границей населенных пунктов - земли сельскохозяйственного назначения, а в горных местностях - земли лесного фонда. Например, в Предгорном районе Ставропольского края, находящегося в составе округа горно-санитарной охраны, есть большое количество родников минеральной воды, изливающихся на поверхность земли. Никаких первых или вторых зон в отношении них нет. Известны случаи передачи земельных участков с такими минеральными источниками в частную собственность.

Таким образом, исходя из фактических реалий, никакого двойного режима земель курортов нет, потому что нет самих земель курортов. С другой стороны, если таких земель нет и кроме упоминания о них в ЗК РФ ни в каких иных нормативно-правовых актах их режим не устанавливается, с точки зрения чистоты правового регулирования, следует отказаться от этой подкатегории земель, оставив только правовое регулирование режима территории округов санитарной или горно-санитарной охраны как основание ограничения прав на землю. Показателен в этом смысле и Приказ Минэкономразвития РФ от 29.10.2013 г. №630 «Об утверждении классификатора видов разрешенного использования земельных участков», где не упоминаются земельные участки из земель курортов, а говорится лишь о курортной деятельности как виде разрешенного использования земельных участков. По мнению Минэкономразвития, разрешенное использование предполагает: использование, в том числе с их извлечением, для лечения и оздоровления человека природных ресурсов (источники минеральных вод, лечебные грязи, рапой лиманов и озер, особый климат), а также охрана лечебных ресурсов от истощения и уничтожения в границах первой зоны округа горно-санитарной или санитарной охраны лечебно-оздоровительных местностей и курорта. Вот уже не только третьей, но и второй зоны не стало.

Что касается имущественных прав на земельные участки на территории курортов КМB, то они представлены всеми известными титулами: и правом собственности, и арендой, и правом постоянного (бессрочного) пользования, и правом пожизненного наследуемого владения. Причем из-за противоречивости законодательства и судебной практики при одних и тех же правоустанавливающих фактах кому-то земельные участки предоставлялись в собственность, кому-то в аренду. До сих пор соседи-собственники жилых домов владеют земельными участками на разных видах права - у одного земельный участок в собственности, у другого в аренде. Поскольку Федеральный закон от 28.12.2013 г. №406-Ф3 "О внесении изменений в Федеральный закон "Об особо охраняемых природных территориях» и отдельные законодательные акты Российской Федерации» исключил курорты из числа особо охраняемых природных территорий, тем самым сняв ограничения на оборот земельных участ- 
ков, предусмотренных ст. 27 ЗК РФ, в настоящее время земельные участки, находящиеся на иных, кроме права частной собственности титулах, могут быть обращены в частную собственность.

Одним из элементов правового режима выступает институт управления. Здесь мы сталкиваемся с множеством органов, наделенных теми или иными полномочиями, связанными с администрированием в области использования и охраны природных ресурсов, расположенных в границах округов в нашем случае, горно-санитарной охраны.

Основное полномочие - распоряжение землями. И здесь свою лепту в нарушение законодательства о курортах вносят органы местного самоуправления. Земельные участки под непрофильное для курортов строительство выделяются не только во второй, но и в первой зоне охраны. Примеров очень много. Большинство из них касается городов Пятигорска (абсолютный лидер) и Ессентуков. Есть примеры и из практики неправомерного выделения земельных участков в Кисловодске. Администрация Пятигорска и вовсе дошла до того, что обратилась в арбитражный суд края с иском к Федеральной кадастровой палате Росреестра по Ставропольскому краю об уменьшении площади первых охранных зон, мотивируя это тем, что они устанавливались в 1985 г и уже не актуальны, и даже более того - препятствуют развитию города. К чести суда требования не были удовлетворены. До этого по решению той же администрации Пятигорска для строительства магазина «Метро» было вырублено 5 га леса. Напомним, что лес на территории курорта с дореволюционных времен высаживался людьми для охраны минеральных источников.

Еще один пример связан с будущим распоряжением землями. Согласно генеральному плану города Пятигорска, утвержденному городской думой (вопрос к законодателю: почему генеральные планы городов-курортов федерального значения утверждаются представительными органами муниципалитетов, а не Правительством РФ?), по данным экологической общественной организации «Солнечный патруль», предполагается «снести» 200 га леса, в том числе на территории Бештаугорского государственного регионального заказника, на горе Машук, горе Бештау, далее - везде. Взамен планируется высадить 7 га леса. Более того, отличившаяся проигранными судебными процессами по уменьшению площади первой охранной зоны администрация Пятигорска обратилась в суд с иском о снятии статуса с государственного природного заказника Бештаугорский. Краевой суд вслед за Пятигорским судом отказал в удовлетворении исковых требований. И произошло это совсем недавно, в ноябре 2014 г Однако, как отмечают экологи-общественники «администрация города намерена и дальше добиваться снятия статуса особой охраны лесов Пятигорска: гор Машук, Бештау, Дубровка» [6].

К предоставлению земельных участков в охранных зонах имеет отношение и Росприроднадзор, который до недавнего времени проводил экологическую экспертизу, зачастую идя на по- воду у администраций. Пример тому - экспертиза проектной документации на строительство якобы, малоэтажного пансионата на западном склоне горы Машук в целях «рекреационного развития города" на месте «внезапно погибшей ореховой рощи». Действительно, во второй зоне разрешено строительство объектов курортной инфраструктуры. Росприроднадзор по Северо-Кавказскому федеральному округу при проведении экологической экспертизы даже не рассматривал вопрос о беспричинной и безвременной гибели рощи, дав положительное заключение. Вскоре, как и предполагала общественность, неоднократно обращавшаяся в прокуратуру по факту незаконного строительства, застройщик обратился в городскую администрацию с просьбой об изменении вида разрешенного использования: строить уже собрались не пансионат, а двухэтажные жилые коттеджи с последующей их продажей Полагаем, что только потому, что ситуация имела общественный резонанс, администрация города не удовлетворила просьбу застройщика. Кстати, уже упоминавшийся Федеральный закон от 28.12.2013 г. №406-Ф3 «О внесении изменений в Федеральный закон «Об особо охраняемых природных территориях» и отдельные законодательные акты Российской Федерации», исключив курорты из числа особо охраняемых природных территорий, автоматически исключил и обязанность по проведению экологической экспертизы документации на строительство объектов на их территории. Проблема заключается еще и в том, что общественные экологические организации, готовые безвозмездно проводить общественную экологическую экспертизу, лишены этого права. Ф3 от 23.11.1995 г. №174-Ф3 «Об экологической экспертизе» допускает ее проведение только в отношении объектов федеральной и региональной экологической экспертизы, перечисленных соответственно в ст. 11 и 12 закона

Еще один орган управления - уже упомянутое Минэкономразвития, «забывшее» про вторую и третью охранную зону при регламентации видов разрешенного использования земельных участков для курортной деятельности.

Что же касается центральной функции - контроля, то речь должна идти как о земельном надзоре (значительный урон природным лечебным ресурсам наносится землепользователями при строительстве), надзоре за рациональным пользованием источниками природных лечебных ресурсов, так и за рациональным пользованием и охраной иных природных ресурсов, в частности лесов, выполняющих важные гидрологические функции.

Здесь «разброс» органов тоже велик. Надзор за соблюдением законодательства по округам горно-санитарной охраны водных объектов, водные ресурсы которых являются природными лечебными ресурсами, осуществляет Росприроднадзор. У него же есть ряд полномочий по земельному надзору. Надзор за санитарно-эпидемиологическим состоянием природных лечебных ресурсов осуществляет Роспотребнадзор. За соблюдени- 
ем земельного законодательства - Росреестр, а в отношении земель сельскохозяйственного назначения (они в основном сосредоточены в третьей зоне) еще и Федеральная служба по ветеринарному и фритосанитарному надзору.

Серьезная работа по выявлению и пресечению правонарушений, связанных с правовым режимом земель курортов КМВ, в последние годы ведется прокуратурой. Именно по представлению прокуратуры края ФГУ «Земельная кадастровая палата» по Ставропольскому краю в государственный кадастр недвижимости были внесены сведения о первой и второй зонах округа горно-санитарной охраны городов-курортов

Возникает вопрос: почему эти проблемы решает прокуратура, а не надзорные органы исполнительной власти?

Теперь о правах и обязанностях субъектов и мерах охраны природных объектов как элементах правового режима. Права граждан и юридических лиц - назовем их владельцами земельных участков, ограничены требованиями соблюдения правового режима земель курортов. Обязанности должны неукоснительно выполняться, а проверять их выполнение призваны также органы надзора и контроля. Помимо общих требований, содержащихся в земельном законодательстве, землевладельцы должны исполнять требования Положения об округах санитарной и горно-санитарной охраны лечебно-оздоровительных местностей и курортов федерального значения, утвержденного постановлением Правительства РФ от 07.12.1996 г. №1425. Однако нарушений обязанностей землевладельцев - огромное количество. Мало того, что вторая зона застроена жилыми домами, производственными объектами. Это вина не землевладельцев, а органов, предоставивших эти участки. Но граждане и юридические лица зачастую не имеют канализации, организуют стихийные свалки и т.д.

В качестве наиболее принципиальных выводов из рассмотренных проблем правового режима земель ЛОМ и курортов можно сформулировать следующие предложения законодателю:

- В Земельный кодекс РФ необходимо ввести норму, запрещающую перевод земель лесного фонда на территории лечебно-оздоровительных местностей и курортов, а также на территории курортных регионов в земли иных категорий (кроме как в земли особо охраняемых территорий и объектов).

- В ч. 2 ст. 94 Земельного кодекса РФ перечень видов земель особо охраняемых территорий и объектов необходимо дополнить землями лечебно-оздоровительных местностей и курортов.

- Из ч. 3 ст. 96 Земельного кодекса РФ необходимо исключить упоминание об особо охраняемых природных территориях, поскольку лечебно-оздоровительные местности и курорты больше не относятся к ним с 2013 года.

- Ч. 3 ст. 96 Земельного кодекса РФ необходимо дополнить указанием на то, что изъятие земельных участков у собственников, землепользователей, землевладельцев и арендаторов при необходимости возможно не только на территории первой, но и второй зоны округа санитарной (горно-санитарной) охраны лечебно-оздоровительных местностей и курортов.

- Статью 262 Уголовного кодекса РФ «Нарушение режима особо охраняемых природных территорий и природных объектов» необходимо дополнить указанием на уголовную ответственность за нарушение законодательства о лечебно-оздоровительных местностях и курортах, изложив не только ее содержание, но и название в новой редакции: «Нарушение режима особо охраняемых природных территорий, лечебно-оздоровительных местностей, курортов и природных объектов»

- Статью 8.39 КоАП РФ «Нарушение правил охраны и использования природных ресурсов на особо охраняемых природных территориях" следует дополнить указанием на административную ответственность за нарушение законодательства о лечебно-оздоровительных местностях и курортах, изложив не только ее содержание, но и название в новой редакции: «Нарушение правил охраны и использования природных ресурсов на особо охраняемых природных территориях, лечебно-оздоровительных местностях и курортах».

- В работе как над фредеральным (проекты фредерального закона №555658-6 и федерального закона о Кавказских Минеральных Водах), так и над региональным законодательством не следует допускать либерализации правового режима трех зон округа санитарной (горно-санитарной) охраны. Режим ограничения в них хозяйственной деятельности должен устанавливаться не ниже того, как он сейчас представлен в п.п. 12-14 Постановления Правительства РФ от 07.12.1996 г №1425 «Об утверждении Положения об округах санитарной и горно-санитарной охраны лечебно-оздоровительных местностей и курортов федерального значения".

- В п. 3 ч. 2 ст. 7 и ст. 10 Федерального закона от 13.07.2015 г. №218-Ф3 «О государственной регистрации недвижимости» среди границ зон с особыми условиями использования необходимо ввести указание на пропущенные там границы округа санитарной (горно-санитарной) охраны лечебно-оздоровительных местностей и курортов.

- В ч. 4 ст. 1 Градостроительного кодекса РФ в числе зон с особыми условиями использования необходимо также упомянуть округа санитарной (горно-санитарной) охраны лечебно-оздоровительных местностей и курортов.

- Ч. 6 ст. 36 и п. 6 ч. 5 ст. 51 Градостроительного кодекса РФ необходимо привести в соответствие с действующим федеральным законодательством, убрав из данных норм упоминание о лечебно-оздоровительных местностях и курортах, поскольку последние с 2013 года больше не относятся к числу особо охраняемых природных территорий. 


\section{Литература}

1. Выпханова Г. В. Концептуальные основы совершенствования законодательства о лечебно-оздоровительных местностях и курортах // Lex Russica. 2016. №6. C. 119-131.

2. Кузнецов Д. В. Ограничения оборота земельных участков в курортных населенных пунктах // Экологическое право. 2011. №4. С. 31-37.

3. Навасардова Э. С., Нутрихин Р. В. Проблемы реализации государственно-правовой курортной политики в современной России // Права человека и правовая культура в системе ценностей гражданского общества и направлений государственно-правовой политики Российской Федерации. Сборник материалов международной научно-практической конференции. Ставрополь: Фабула, 2018. С.101-103.

4. Навасардова Э. С., Нутрихин Р. В. Некоторые аспекты совершенствования российского законодательства о курортах на современном этапе // Гуманитарные и юридические исследования. Научно-теоретический журнал. 2018. №3. C. $162-167$.

5. Навасардова Э. С., Нутрихин Р. В., Колесникова К. В. Состояние и тенденции развития эколого-курортного законодательства в Российской Федерации // Приоритетные направления развития экологического, земельного и аграрного права. Материалы Республиканского круглого стола, приуроченного кюбилею д-ра юрид. наук, проф. Т. И. Макаровой. Минск: Издательский центр БГУ, 2017. С.168-171.

6. Открытое письмо Президенту России регионального экологического движения «Солнечный патруль» (Пятигорск). URL: http://www.kavkaz-uzel.ru/articles/199684/ (Дата обращения: 10.10.2019).

7. Постановление Правительства РФ от 17.01.2006 г. №14 «О признании курортов Ессентуки, Железноводск, Кисловодск и Пятигорск, расположенных в Ставропольском крае, курортами федерального значения и об утверждении Положений об этих курортах» // СПС «КонсультантПлюс».

8. Постановление Совета Министров РСФСР от 9 июля 1985 г. №300 «Об установлении границ и режима округа санитарной охраны курортов Ессентуки, Железноводск, Кисловодск и Пятигорск в Ставропольском крае» // СПС «КонсультантПлюс».

9. Садовская О. В. О влиянии изменений законодательства на правовой режим курортов // Евразийский юридический журнал. 2014. №4. С. 99-101.

\section{References}

1. Vyphanova G. V. Konceptual'nye osnovy sovershenstvovanija zakonodatel'stva o lechebno-ozdorovitel'nyh mestnostjah i kurortah (Conceptual bases of improvement of the legislation on medical and improving areas and resorts) // Lex Russica. 2016. No. 6. P. 119-131. (In Russian)

2. Kuznecov D. V. Ogranichenija oborota zemel'nyh uchastkov v kurortnyh naselennyh punktah (Restrictions of a turn of the land plots in resort settlements) // Jekologicheskoe pravo. 2011. No. 4. P. 31-37. (In Russian)

3. Navasardova Je. S., Nutrihin R. V. Problemy realizacii gosudarstvenno-pravovoj kurortnoj politiki v sovremennoj Rossii (Problems of implementation of state and legal resort policy in modern Russia) // Prava cheloveka i pravovaja kul'tura $v$ sisteme cennostej grazhdanskogo obshhestva i napravlenij gosudarstvenno-pravovoj politiki Rossijskoj Federacii. Sbornik materialov mezhdunarodnoj nauchno-prakticheskoj konferencii. Stavropol': Fabula, 2018. P. 101-103. (In Russian)

4. Navasardova Je. S., Nutrihin R. V. Nekotorye aspekty sovershenstvovanija rossijskogo zakonodatel'stva o kurortah na sovremennom jetape (Some aspects of improvement of the Russian legislation on resorts at the present stage) // Gumanitarnye i juridicheskie issledovanija. Nauchno-teoreticheskij zhurnal. 2018. No. 3. P. 162-167. (In Russian)

5. Navasardova Je. S., Nutrihin R. V., Kolesnikova K. V. Sostojanie i tendencii razvitija jekologo-kurortnogo zakonodatel'stva V Rossijskoj Federacii (State and trends of development of the ecological-resort legislation in the Russian Federation) /I Prioritetnye napravlenija razvitija jekologicheskogo, zemel'nogo i agrarnogo prava. Materialy Respublikanskogo kruglogo stola, priurochennogo k jubileju d-ra jurid. nauk, prof. T.I. Makarovoj. Minsk: BSU publ., 2017. P.168-171. (In Russian)

6. Otkrytoe pis'mo Prezidentu Rossii regional'nogo jekologicheskogo dvizhenija «Solnechnyj patrul'» (Pjatigorsk). (Open letter to the President of Russia of the regional ecological movement «Solar Patrol» (Pyatigorsk)). URL: http://www.kavkazuzel.ru/articles/199684/ (Accessed: 10.10.2019). (In Russian)

7. Postanovlenie Pravitel'stva RF ot 17.01.2006 g. №14 «O priznanii kurortov Essentuki, Zheleznovodsk, Kislovodsk i Pjatigorsk, raspolozhennyh v Stavropol'skom krae, kurortami federal'nogo znachenija i ob utverzhdenii Polozhenij ob jetih kurortah" (The resolution of the Government of the Russian Federation of 17.01.2006 No. 14 "On recognition of the resorts of Yessentuki, Zheleznovodsk, Kislovodsk and Pyatigorsk located in Stavropol Region, resorts of federal importance and on the adoption of Regulations on these resorts») // SPS «Konsul'tantPljus». (In Russian)

8. Postanovlenie Soveta Ministrov RSFSR ot 9 ijulja $1985 \mathrm{~g}$. №300 «Ob ustanovlenii granic i rezhima okruga sanitarnoj ohrany kurortov Essentuki, Zheleznovodsk, Kislovodsk i Pjatigorsk v Stavropol'skom krae») (Resolution of Council of ministers of RSFSR of July 9, 1985 No. 300 "On establishment of borders and mode of the district of sanitary protection of the resorts of Yessentuki, Zheleznovodsk, Kislovodsk and Pyatigorsk in Stavropol Region") // SPS "Konsul'tantPljus». (In Russian)

9. Sadovskaja O. V. O vlijanii izmenenij zakonodatel'stva na pravovoj rezhim kurortov (On the impact of changes of the legislation on a legal regime of resorts) // Evrazijskij juridicheskij zhurnal. 2014. No.4. P. 99-101. (In Russian) 


\section{Сведения об авторах}

Навасардова Элеонора Сергеевна - доктор юридических наук, профессор, заведующая кафедрой экологического, земельного и трудового права юридического института Северо-Кавказского федерального университета (Ставрополь) / navasardova@yandex.ru

Чечель Григорий Иванович - доктор юридических наук, профессор кафедры уголовного права и процесса юридического института Северо-Кавказского федерального университета (Ставрополь) / ug pravo11a@mail.ru

Нутрихин Роман Владимирович - кандидат юридических наук, доцент кафедры экологического земельного и трудового права юридического института Северо-Кавказского федерального университета (Ставрополь) / nut-roman@yandex.ru

\section{Information about the authors}

Navasardova Eleonora - Doctor of Law, Professor, Head of Department of Environment, Land and Labor Right, Institute of Law, North-Caucasus Federal University (Stavropol) / navasardova@yandex.ru

Chechel Gregoriy - Doctor of Law, Professor of Department of Penal Law and Process, Institute of Law, North-Caucasus Federal University (Stavropol) / ug_pravo11a@mail.ru

Nutrikhin Roman - Doctor of Law, Docent of Department of Environment, Land and Labor Right, Institute of Law, North-Caucasus Federal University (Stavropol) / nut-roman@yandex.ru 